\title{
Empowering certified garlic seed producers to increase local production in Sembalun highlands of Eastern Lombok, Indonesia
}

\author{
Mardiana*, Sylvia Kusumaputri Utami, and Baiq Nurul Hidayah \\ West Nusa Tenggara Assessment Institute for Agricultural Technology (Balai Pengkajian Teknologi \\ Pertanian), West Nusa Tenggara Province, 83371 Indonesia
}

\begin{abstract}
Garlic demand in Indonesia reaches 500,000 tons yearly and $82.5 \%$ supplied from importation. This problem could be addressed by increasing national production. However, garlic production is very dependent on seeds availability, therefore efforts to produce high quality seeds is a must. One of the efforts is through developing certified garlic seed producers. This research aims to study efforts by Assessment Institute for Agricultural Technology (AIAT) West Nusa Tenggara Province, Indonesia in empowering growth of new certified seed producers in Lombok Island. Data obtained through in-depth interviews with existing seed producers, new seed producers, community leaders and garlic farmers during 2017-2018. The results showed that formation of two new certified seed producers could increase the coverage of farmers who are assisted from the previous 10 to 20 farmers per group who have a commitment to work together to sell their garlic seeds. Seed producers can be a communication channel that increases farmers' knowledge on garlic cultivation because of an increasingly extensive network and sources of information. Supervising process to new certified seed producers enabling them to produce high quality seeds. In addition, certified garlic seeds produced are easier to recognize by buyers and able to penetrate national market with competitive prices.
\end{abstract}

\section{Introduction}

Garlic (Allium sativum L.) is a very important commodity because it is used for various purposes, such as cooking spices, medicines, and cosmetic ingredients [1], it is the 14th most important vegetable crop in the world [2] and secondly most consumed plant among the Allium genus worldwide [3]. The consumption of garlic in Indonesia is $1.71 \mathrm{~kg}$ per capita per year [4]. As the population increases, the demand also increases every year. It is unfortunate that about $82.5 \%$ of all domestic garlic needs are supplied through imports [5].

A very significant increase in imports began since the free trade era in 1998. The free trade policy that freed garlic products from abroad to enter Indonesia without high import taxes caused the price of imported garlic to be cheaper than local garlic [6].

\footnotetext{
* Corresponding author: mardiana.hakim@gmail.com
} 
The absence of protection causes local garlic to have full competition with imported garlic. In fact, economically, local garlic production costs are much higher than imported garlic. Importers can sell garlic at a price of Rp. $3000 / \mathrm{kg}$, while in local garlic cultivation, the production costs excluding transportation and depreciation costs have touched the figure of Rp. $3.617 / \mathrm{kg}$. If productivity can be increased at the same cost of production, then prices at the consumer level can be lowered so that their competitiveness is higher [4].

When compared between local garlic and imported garlic, it is known that local garlic has a higher antioxidant content than imported garlic and has a sharper aroma [7]. However, until now there has not been found a breeding technology that allows the size of local garlic to match the size of large imported garlic. One of the important factors that causes consumers to choose imported garlic is because of its large size, making it easier for the peeling and processing [8]. Likewise, industries that use garlic a lot as raw material prefer to use large garlic to reduce wasted by-products because the processing machine has been designed in such a way to peel and cut large-sized garlic [4].

However, there is one interesting finding which can be an entry point for the revival of local garlic. It is stated that the consumer's first consideration in determining the choice of garlic is the price factor. This is evidenced when the price of imported garlic rises sharply, consumers switch to cheaper local garlic even though it has a smaller size. Thus it can be said that compared to the size or aroma of garlic, the price factor is more important for household level consumers. This shows that the biggest challenge in reducing imports is to make local garlic prices as competitive as possible compared to imported garlic. It means that increasing the productivity of local garlic is an absolute thing to do in addition to implementing strict price regulation policies on imported garlic and expanding the planting area [9].

The current decline in productivity can be caused by reduced production inputs from what they should be, as well as the use of poor quality seeds, thereby reducing productivity. Currently, the seeds used by farmers are the seeds of their harvest which are deliberately set aside for seeds [4]. Whereas seeds are one of the production inputs that have a significant contribution to the productivity. The use of high-quality seeds can guarantee growth performance, plant growth uniformity, and produce high yields [10]. This further strengthens the reason for the importance of growing new certified garlic seed producers in this area so that quality seeds can be obtained on time in sufficient quantities as needed. The more seed producers that produce quality seeds, the self-sufficiency of seeds will be achieved which in turn will accelerate the achievement of garlic self-sufficiency. This paper aims to describe the efforts of growing garlic seed producers in order to increase the production of garlic seeds in the Sembalun highlands of Eastern Lombok, Indonesia.

\section{Methodology}

This study was conducted from December 2017 to October 2018 as an action research. This study was conducted in the Sembalun highlands, East Lombok Regency, West Nusa Tenggara (WNT) Province, Indonesia in the form of technical and administrative assistance to cooperating farmers who will be used as prospective seed producers. Technical assistances were provided so that prospective seed producers apply cultivation techniques in accordance with the Good Agriculture Practices (GAP) standards set by the Seed Certification Supervisory Agency (BPSB). Administrative assistances were conducted as part of fulfilling legal requirements to comply with applicable laws and regulations.

Data collected includes primary and secondary data. Primary data collection was obtained by recording each mentoring process, conducting in-depth interviews with cooperating farmers regarding the results and constraints faced, as well as to interested parties, in this case the certification agency. Secondary data was obtained from the 
Statistical Bureau report, as well as data released by the Indonesian Ministry of Agriculture.

The data obtained were tabulated and analyzed descriptively.

\section{Results and discussion}

\subsection{Current condition of garlic industry in Indonesia}

The high value of imports makes garlic can be said to be the main crushing commodity for the country's foreign exchange. If accumulated from 2015 to 2019, the country's foreign exchange that comes out within five years due to garlic imports is very high, almost reaching US\$ 600 million or the equivalent of 35 trillion rupiah (Figure 1).

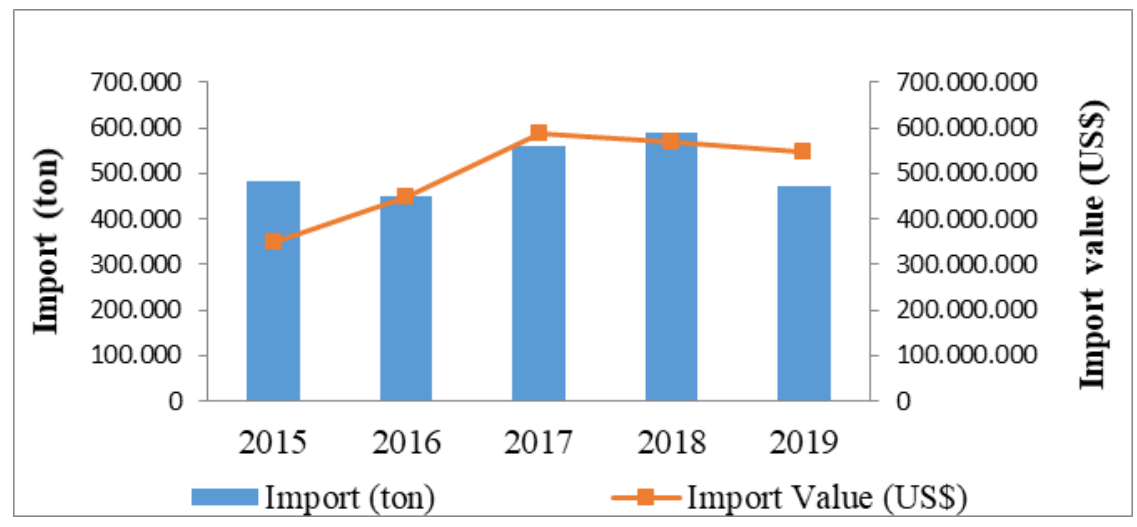

Fig. 1. Trend of garlic importation and import value in Indonesia during the periode of 2015-2019 [9]

Figure 2 shows that the productivity of garlic in the province of WNT Province is among the highest compared to other regions in Indonesia, with the second number of production after Central Java Province. The current productivity is only around 10.75 tons/ha, far below the results achieved in the 1980s which ranged from 30-40 tons/ha. It is noted that around the 1980s, the Sembalun area in WNT Province was a "white gold" area because it was the center of garlic production at that time. Even now, in the midst of the crisis, the decline in the number of farmers who plant and grow garlic, has not dampened the position of WNT as the main producer of garlic in Indonesia [11].

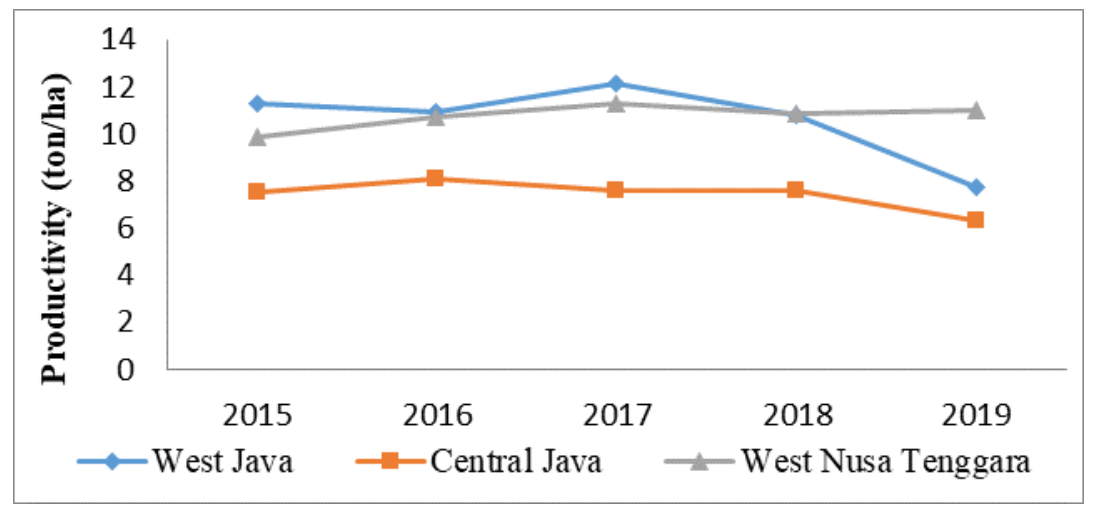

Fig. 2. Trend in productivity of garlic in the top three provinces of garlic producing areas in Indonesia during the periode of 2015-2019 
While the total production of garlic in top three provinces is shown in Figure 3. In the last five year, total production of garlic from WNT province was the second place after Central Java Province.

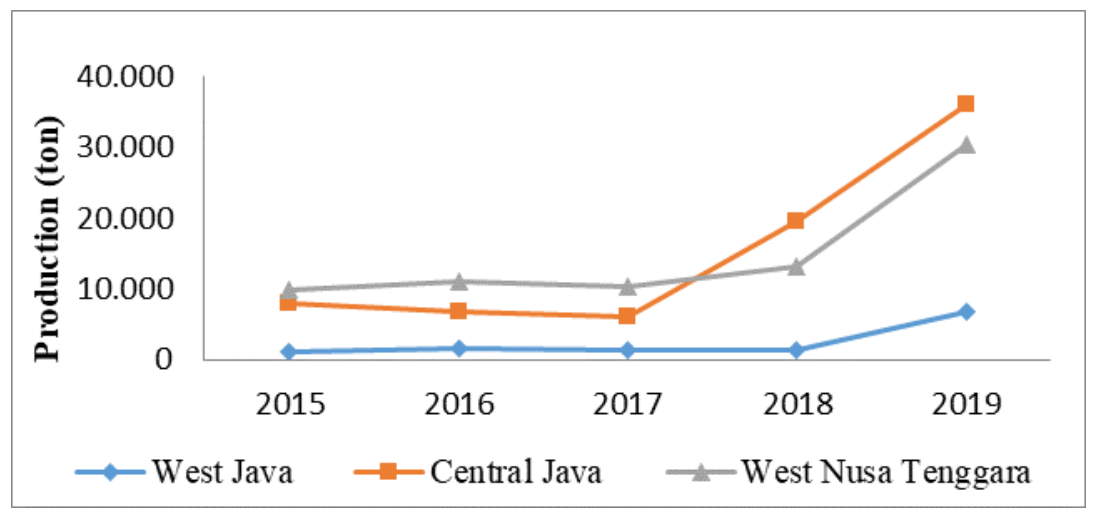

Fig. 3. Trend of garlic total production among the top three provinces of garlic producing areas in Indonesia during the periode of 2015-2019 [12]

\subsection{Empowering certified garlic seed producers in Sembalun highlands}

\subsubsection{Assistance from the West Nusa Tenggara AIAT}

West Nusa Tenggara Assessment Institute for agricultural Technology was giving technical assistance to the prospective seed producers in adapting to the principles of applying GAP, including land preparation, seed preparation and planting, fertilization, irrigation, maintenance, pest and disease control, harvest and post-harvest.

Technical assistance was given due to administrative problems often become complex and take time to implement, so farmers tend to be less aware and accustomed to taking care of the administration. Whereas administration is authentic evidence of the legitimacy of a seed being certified. This tends to be complex so it requires assistance to prospective seed producers. In addition, institutional assistance for prospective seed producers so that they are able to organize other farmers to become partners so that production capacity can be increased.

The main purpose of seed certification is to protect consumers from obtaining seeds that are not correct in terms of variety or quality. Technical and administrative assistance for prospective seed producers was conducted to ensure that prospective seed producers are able to meet all requirements in accordance with the Standard Operational Procedure (SOP) for garlic seeds.

In general, the requirements for seed certification based of certification agency (BPSB) are as follows: 1) The applicant for certification must be registered with the BPSB, comply with applicable regulations, control the land/captive area, control the source seed and be able to pay the certification fee; 2) The source seed or seed to be cultivated must have been released, the seed class is higher than the seed class to be produced and can be traced, meaning that the seed document must be complete and clear; 3) The land or area for certification must have clear boundaries, one area may only be planted with one class of seed and one variety, free from other plants or fallow and not planted with plant species of the same family for several seasons. The area for certification of field history must be clear, one area can consist of several plots with a maximum distance of 10 meters and a maximum planting time difference of 7 days; and 4) The applicant is obligated to conduct 
selection (roguing) to remove the types of intersections and other varieties and to maintain the crops.

\subsubsection{Certification procedure}

Certification procedures are grouped into two: general and specific. Procedures generally involve applications, preliminary examinations and re-examinations. While special procedures apply to each group of seed forms. General Procedures are: 1) Seed producers must submit an application to BPSB at least 7 days before the inspection is carried out. The application must be accompanied by a captive map/plan or map/plan of the location of the scion parent tree and proof of the feasibility of the parent tree; 2) Preliminary examination. This inspection is carried out on the correctness of the name and address of the applicant, the land for certification and the source seed which includes the origin of the seed, class of seed, variety and volume of seed to be planted in accordance with the captive area; 3 ) Recheck. This inspection may only be carried out once at each inspection stage provided that the seed producer must improve field conditions and the growth phase at the inspection stage has not ended.

Special procedures for certification of tuber seeds are as follows: 1) Plant inspection. The first assessment is in the growth phase. Parameters observed were growth type, stem color, leaf color and shape, other varieties and types of intersections as well as plant health. The second inspection is in the pre-harvest phase. Parameters observed were type of growth, other varieties and types of intersections, color and shape of tubers and plant health; 2) Bulb inspection. Inspection of bulbs is carried out after harvesting, sorting, making lots and before packaging which is focused on other varieties, pest attack and mechanical damage; 3) Giving certificates and labels: Certificates and labels are given only to seed lots that have passed field inspections and bulb inspections in the warehouse. Labels are attached to each package with a minimum label content of plant type/variety, seed class, packaging volume, lot number, name and address of producer, chemical treatment, harvest date. The color of the label is white for basic seeds, purple for main seeds, and blue for spread seeds.

\subsubsection{Advantages of being a seed producer}

Some advantages for being seed producers are: 1) Better known for having a label. With the label, seed producers can more easily introduce the seed products they produce to consumers. Product labels are the identity of a product to be marketed, product labels can make it easier for consumers to choose the products to buy and become a business branding amplifier in increasingly fierce business competition. In the label on the product there is information in the form of brand, composition, legality, function and product instructions [10]. In the case of auctions for the procurement of goods and services, one of the requirements for a product to be included is to have a label so that it can be identified where the product comes from; 2) Items are quickly searched by others, more preferred. Consumers, in this case farmers, have a better level of trust in products that have gone through a certification test, so they can attach an official label. The strength of certification is the assurance of a product because it has complied with all the required rules. The benefits are obtained on the part of producers and consumers. Producers have a better bargaining position on the goods they produce while consumers have certainty/guarantee on the goods/products consumed [13]; 3) The selling price of certified seeds is better than that of non-certified seeds. Seed producers in this case can get a price difference of Rp. $10,000 / \mathrm{kg}$ when compared between labeled/certified seeds and unlabeled seeds. This is in accordance with what was conveyed by Herudiansyah et al. [14] which stated that with a 
certification process that issues labels on products, seed producers can sell products at better prices so that they get greater profits; 4) There is quality control from the authorities, including assistance, so that if there are obstacles or things that could interfere with seed production, they can be anticipated and resolved more quickly. The certification process involves BPSB from start to finish, so that plant growth can be monitored. For example, during inspection, if it is found that there are plants that grow not uniformly and the seed producers have to let the plants be uprooted and it can reduce yields, in the end the results obtained are uniform and much better than without roughing. Likewise, the presence of pests and diseases can be anticipated immediately so as not to cause greater losses [13]; 5) Expanding the network of cooperation and coaching to other farmers who are smaller in capacity, in addition to the members of the existing farmer groups. In the past, only 10 people were members of farmer groups, now there are 20 people who are committed to selling their crops. This cooperation commitment allows the assisted farmers to obtain adequate production inputs and information on technology, as well as certainty that their crops will be purchased. This kind of collaboration is closer to the Plasma Core model [15]. Some of the advantages obtained with the Plasma Core system approach are described in Table 1 .

Table 1. Some advantages of the Plasma Core system approach

\begin{tabular}{|c|c|c|}
\hline \multirow{2}{*}{ Aim of Partership } & \multicolumn{2}{|c|}{ Advantage } \\
\hline & Core & Plasma \\
\hline Economical aspect & $\begin{array}{l}\text { - availability of materials for } \\
\text { production and increasing of } \\
\text { profit } \\
\text { - No need for renting production } \\
\text { area }\end{array}$ & $\begin{array}{l}\text { - Increasing of income } \\
\text { - Farmers' land could be used } \\
\text { optimally and lead to increase } \\
\text { productivity }\end{array}$ \\
\hline Social aspect & $\begin{array}{l}\text { - Social responsibility for } \\
\text { supervising farmers }\end{array}$ & $\begin{array}{l}\text { - Farmers' capacity growth due } \\
\text { to mentoring process } \\
\text { - Production continuity lead to } \\
\text { decrease unemployer }\end{array}$ \\
\hline Technological aspect & $\begin{array}{l}\text { - Increasing productivity and } \\
\text { efficiency } \\
\text { - Having capital which lead to } \\
\text { access on technology }\end{array}$ & $\begin{array}{l}\text { - Farmers need update } \\
\text { technology but did not have } \\
\text { access therefore partnership } \\
\text { system make eaiser to get } \\
\text { information freely }\end{array}$ \\
\hline Management aspect & - Increasing work productivity & $\begin{array}{l}\text { - Increasing of farmers' } \\
\text { productivity lead to } \\
\text { increasing of farmers' } \\
\text { welfare }\end{array}$ \\
\hline
\end{tabular}

\subsubsection{Obstacles encountered}

In the process of growing seed producers, there are various challenges that must be faced. It is not easy to get farmers who have the commitment to become prospective seed producers with various existing requirements. Prospective seed producers must be given the belief that becoming a seed producer will have a far greater economic and social impact than being an ordinary farmer. Another obstacle is in terms of government policies in determining programs and budgets. Ideally, to achieve seed self-sufficiency, many seed producers are needed so the program should run on a multi-year or sustainable basis. However, what often happens is that the roadmap or long-term strategy is not implemented so that the program has not achieved results and has been discontinued. This requires a strong commitment (political will) from the government to carry out policies that are pro to the people so that self-sufficiency in seeds and garlic in general can be achieved. 


\section{Conclusion}

One of the important aspects to achieve self-sufficiency in garlic is the achievement of seed self-sufficiency which is indicated by the availability of quality garlic seeds in adequate quantities and on time. The greater the number of garlic seed producers, the faster the seed self-sufficiency can be achieved. Assistance that is done properly and correctly will be able to grow quality seed producers.

\section{References}

1. C. Aaron, the North American Rev. 281, 2, 14-24 (1996)

2. Food and Agriculture Organization of the United Nations, FAO Statistics, www.fao.org (2011)

3. Food and Agriculture Organization of the United Nations, FAO Statistics, http://faostat3.fao.org/home/E (2018)

4. A. M. Kiloes, I. W. Arsanti, Tantangan dan harapan bawang putih nasional, Pendekatan dinamika system dalam peningkatan daya saing komoditas hortikultura (IAARD Press, Jakarta, 2015)

5. Centre of Statistical Bureau, Horticultural Statistics 2019 (Centre of Statistical BureauStatistics Indonesia, Jakarta (2020)

6. Haryono, M. P. Yufdy, R. A. Nugrahapsari, Kebijakan Penelitian dan Pengembangan Hortikultura Untuk Meningkatkan Daya Saing di Era Masyarakat Ekonomi ASEAN', Pendekatan Dinamika Sistem Dalam Peningkatan Daya Saing Komoditas Hortikultura (IAARD Press, Jakarta, 2015)

7. U. Fitrotin, B. N. Hidayah, Int. J. Biosci. Biochem. and Bioinform. 9, 3, 180-187 (2019)

8. M. Ameriana, Perbaikan kualitas sayuran berdasarkan preferensi konsumen, Monograf No. 17 (Balitsa, Lembang, 1998)

9. A.M. Kiloes, G.A. Sopha, IAARD Press (2015)

10. S.H. Mulya, A. Ruskandar, A. Setyono, P. Wardana, Studi peran Lembaga produsen benih terhadap upaya pengembangan penangkaran benih bermutu, in Prosiding Seminar Nasional Padi (2008)

11. Mardiana, S. K. Utami, B. N. Hidayah, Local wisdom of garlic cultivation in Sembalun highland of Lombok Island, in Proceedings of International Symposia on Horticulture, ICHORD-IAARD, 27-30 November 2018, Kuta Bali, Indonesia (2018)

12. Kementerian Pertanian Republik Indonesia, Horticulture sub sector data (Kementan RI, 2020)

13. H. Mayrowani, Forum Penelit. Agro Ekon. 30, 2, 91-108 (2012)

14. G. Herudiansyah, M. Candera, R, Pahlevi, J. Ilm. Pengabdi. Kpd. Masy. 1, 2, 84-89 (2019)

15. M. Fitri, R. Afrizal, Yuliandri, J. Agribus. and Community Empowerment 1, 1, 28-37 (2018) 